\title{
TINJAUAN KEAKURATAN KODEFIKASI TINDAKAN KASUS BEDAH PASIEN RAWAT INAP TAHUN 2017
}

\section{CODING ACCURACY ON SURGICAL CASE INPATIENTS IN 2017}

\author{
Gugun Priyadi ${ }^{1 *}$,Cahyani Dwi Lestari ${ }^{2}$ \\ 1, 2 Prodi Perekam Medis dan Informasi KesehatanPoltekkes Kemenkes Tasikmalaya \\ kangpriyadi9@gmail.com, cahya91@gmail.com
}

\begin{abstract}
ABSTRAK
Unit rekam medis di rumah sakit, salah satu bagian utama-nya adalah bagian koding. Koding terbagi menjadi 2, yaitu koding diagnosis dan koding tindakan. Koder bertanggungjawab atas keakuratan kode dari suatu diagnosis yang ditetapkan oleh tenaga kesehatan. Tujuan penelitian mengetahui akurasi kodefikasi tindakan kasus bedah pasien rawat Inap Tahun 2017. Dalam studi pendahuluan ditemukan $73,33 \%$ kode tindakan yang tidak tepat , dan $26,67 \%$ kode tindakan yang tepat. Jenis penelitian kuantitatif dengan pendekatan deskriptif, Populasi dalam penelitian ini adalah dokumen rekam medis dengan Lembar Ringkasan Masuk dan Keluar Pasien Bedah Rawat Inap baik Umum maupun BPJS, diperkuat dengan melihat Resume medis, Lembar Operasi, didukung dengan melihat Lembar Anamnesa, Lembar Pemeriksaan Penunjang dan Catatan Terintegrasi Sampling Purposive, menggunakan rumus Slovin. Hasil Penelitian yang dilakukan dengan sampel 94 rekam medis kasus bedah ditemukan $43,6 \%$ kode tindakan akurat dan $56,4 \%$ kode tidak akurat. Kode akurat banyak ditemukan pada kasus bedah kandungan terutama SC, bedah urologi dan bedah lainnya, sehingga koder lebih mudah untuk memberikan kode karena sudah hafal. Sedangkan kode tidak akurat banyak dijumpai pada kasus bedah orthopedic dan kasus lainnya dengan penyebab kesalahan paling banyak karena kesalahan kategori dan tidak spesifik. Beberapa factor ketidak akurat kode salah satunya adalah kesulitan koder dalam membaca tulisan dan singkatan yang dibuat oleh dokter.
\end{abstract}

Kata Kunci : Keakuratan Koding, Kode Tindakan, ICD-9 CM.

\begin{abstract}
.
In the medical record unit in the hospital, one of the main parts is the coding section. Coding is divided into 2 , namely coding of diagnosis and coding of action. The coder is responsible for the accuracy of the code of a diagnosis determined by the health worker. The research objective was to determine the accuracy of the codification of surgical cases for inpatients in 2017. In the preliminary study, $73.33 \%$ of the code of action was not correct, and $26.67 \%$ of the code of action was correct. This type of quantitative research uses a descriptive approach, the population in this study is a medical record document with a Summary Sheet of Entry and Exit of Inpatient Surgery for General and BPJS patients, strengthened by looking at medical resumes, surgery sheets, supported by looking at the history sheet, supporting examination sheets and notes. Integrated Sampling Purposive, using the Slovin formula. Results The study was conducted with a sample of 94 medical records of surgical cases found that $43.6 \%$ of the code of action was accurate and $56.4 \%$ of the codes were inaccurate. Accurate codes are found in many cases of gynecological surgery, especially SC, urological surgery, and other surgeries, so the coder is easier to give the code
\end{abstract}


because it is memorized. Meanwhile, inaccurate codes were found in many cases of orthopedic surgery and other cases where the cause of errors was mostly due to categorical and non-specific errors. Some of the factors in the code's inaccuracy were the coder's difficulty in reading the writings and abbreviations made by doctors.

Keywords: Coding Accuracy, Action Code, ICD-9 CM.

\section{PENDAHULUAN}

Salah satu tugas Unit Rekam Medis di rumah sakit adalah Koding dan Indeksing. Koding terbagi menjadi 2, yaitu koding diagnosis dan tindakan. Kodefikasi harus dilakukan dengan tepat karena dapat mempengaruhi data Mortalitas, Morbiditas serta statistik Rumah Sakit yang berguna untuk evaluasi mutu pelayanan yang diberikan. Namun, ${ }^{2}$ menurut penelitian Ardyanta (2014) yang dilakukan di RS Panti Rapih Yogyakarta, terdapat $42.88 \%$ kode tindakan yang tidak sesuai dan $57.12 \%$ kode tindakan yang sesuai karena faktor penulisan yang kurang jelas juga karena kurangnya SDM ${ }^{1}$.

Keakuratan kode Tindakan Pasien Bedah pada rekam medis di Rumah Sakit Sumber Waras belum optimal. Dalam studi pendahuluan ditemukan $73,33 \%$ kode tindakan yang tidak tepat, dan $26,67 \%$ kode tindakan yang tepat. Hal ini karena pegawai rekam medis di Rumah Sakit sumber waras memiliki banyak job desk yang harus dikerjakan dalam per-shiftnya. Selain itu, terbatasnya ketersediaan ICD-9-CM di Ruang Rekam Medis juga mempengaruhi tidak dilakukannya proses kodefikasi kode tindakan. Melihat betapa pentingnya keakuratan kodefikasi tindakan, peneliti tertarik untuk meneliti Keakuratan Kodefikasi Tindakan Kasus Bedah Pasien Rawat Inap pada Instalasi Bedah Sentral berdasarkan ICD-9CM dalam Lembar Ringkasan Masuk dan Keluar di Rumah Sakit Sumber Waras Semester II Tahun 2017.

\section{METODE}

Jenis penelitian yang dipakai pada penelitian ini adalah kuantitatif dengan pendekatan deskriptif.
Penelitian ini bertujuan untuk mengetahui tingkat keakuratan kode Tindakan Bedah pada Lembar Ringkasan Masuk dan Keluar Pasien Rawat Inap di Instalasi Bedah Sentral Rumah Sakit Sumber Waras Semester II Tahun 2017. Populasi dalam penelitian ini adalah Dokumen Rekam Medis dengan Lembar Ringkasan Masuk dan Keluar Pasien Bedah Rawat Inap Umum dan BPJS di Rumah Sakit Sumber Waras. Teknik pengambilan sampel adalah Purposive Sampling. Populasi yang diambil adalah data pasien operasi di Instalasi Bedah Sentral Rumah Sakit Sumber Waras pada semester II tahun 2017 sebanyak 1509 Operasi dengan penghitungan jumlah populasi yang diteliti menggunakan rumus Menurut Slovin ${ }^{2}$

$$
n=\frac{N}{1+N\left(d^{2}\right)}
$$

Jadi,untuk populasi 1509 dengan tingkat kesalahan $10 \%$ jumlah sampelnya 94 . Sejumlah 94 sampel ini dibagi secara merata sebanyak 7 bedah sehingga setiap bedah mengambil 13 Sampel.

\section{HASIL}

Persentase Keakuratan Kodefikasi Tindakan pada Lembar Ringkasan Masuk dan Keluar Kasus Bedah Pasien Rawat Inap di Instalasi Bedah Sentral.

Keakuratan Kodefikasi Tindakan Bedah di RS Sumber Waras Kabupaten Cirebon berdasarkan pada Formulir: Lembar Ringkasan Masuk dan Keluar,Item yang dilihat : Tindakan/Operasi dan Kode ICD-9-CM, Resume,Item yang dilihat :Anamnesa, Pemeriksaan Penunjang dan 
Tindakan/Prosedur,Lembar Operasi, Item yang dilihat : Diagnosis Preoperasi, Diagnosis Post Operasi, Tindakan, Lembar Anamnesa, Item yang dilihat : Anamnesa dan Lembar Pemeriksaan Penunjang, Item yang dilihat : Hasil-hasil pemeriksaan penunjang serta Catatan Terintegrasi, Item yang dilihat : SOAP apabila ada informasi yang kurang.

Tabel 1 Persentase Keakuratan Kodefikasi Tindakan Bedah di RS Sumber Waras Semester II Tahun 2017

\begin{tabular}{lcc}
\hline $\begin{array}{c}\text { Keakuratan } \\
\text { kodefikasi } \\
\text { tindakan } \\
\text { Bedah }\end{array}$ & Frekuensi & Persentase \\
\hline Akurat & 41 & $43,6 \%$ \\
Tidak Akurat & 53 & $56,4 \%$ \\
\hline Total & 94 & $100 \%$ \\
\hline Sumber: Data & sekunder RS Sumber Waras \\
(2017). & &
\end{tabular}

Berdasarkan hasil penelitian dari 94 sampel rekam medis pasien dengan kasus pasien bedah pada tahun 2017 terdapat 41 atau $43,6 \%$ rekam medis dinyatakan akurat dan 53 atau $56,4 \%$ rekam medis yang tidak akurat.

\section{Ketidakakuratan Kode Tindakan pada Lembar Ringkasan Masuk dan Keluar Kasus Bedah Pasien Rawat Inap di Instalasi Bedah Sentral.}

Koding yang tidak akurat dari 94 sampel Rekam Medis Pasien dengan kasus pasien bedah pada tahun 2017 ada 53 atau 56,4\% rekam medis, dapat dilihat dari hasil perhitungan pada table 2 Terdapat 6 penyebab kesalahan kode yang menjadi alasan dari ketidak akuratan, antara lain:

Tabel 2 Uraian Ketidak Akuratan Koding

\begin{tabular}{|c|c|c|}
\hline $\begin{array}{c}\text { Penyebab } \\
\text { Kesalahan kode }\end{array}$ & Frekuensi & Prosentase \\
\hline $\begin{array}{l}\text { Kesalahan } \\
\text { Kategori }\end{array}$ & 17 & $32,1 \%$ \\
\hline Tidak Spesifik & 15 & $28,3 \%$ \\
\hline $\begin{array}{l}\text { Kesalahan Sub } \\
\text { Kategori }\end{array}$ & 9 & $17,0 \%$ \\
\hline $\begin{array}{l}\text { Dari 2-3Tindakan } \\
\text { hanya satu yang } \\
\text { dikode }\end{array}$ & 8 & $15,1 \%$ \\
\hline Kesalahan Blok & 3 & $5,7 \%$ \\
\hline $\begin{array}{l}\text { Kesalahan } \\
\text { Chapter }\end{array}$ & 1 & $1,9 \%$ \\
\hline Total & 53 & $100 \%$ \\
\hline
\end{tabular}

Berdasarkan Tabel 2 berupa Uraian Ketidak akuaratn koding, Penyebab kesalahan terbanyak pada kategori tidak spesifik sebesar $32,1 \%$ kategori tersebut berupa ketidak jelasan jenis tindakan operasi apa yang dilaksanakan. Ketidak akuratan terkecil pada pemilihan berdasarkan Chapter dalam koding ICD-9-CM sebanyak $1,9 \%$.

\section{PEMBAHASAN}

Persentase Keakuratan Kodefikasi Tindakan pada Lembar Ringkasan Masuk dan Keluar Kasus Bedah Pasien Rawat Inap di Instalasi Bedah Sentral.

Kodefikasi tindakan bedah terdiri dari Operation (OR) Procedure dan Non OR Procedure but affects ThaiDRG. OR Procedure adalah tindakan bedah, berbeda dengan Non $O R$ Procedure karena Non OR Procedure adalah tindakan namun bukan pembedahan. Kodefikasi tindakan kasus bedah berdasarkan ICD-9-CM. Keakuratan kodefikasi Tindakan Bedah pada 94 sampel rekam medis diperoleh dari hasil perhitungan bahwa data yang akurat sebanyak $44.1 \%$ rekam medis dan yang tidak akurat sebanyak $55.9 \%$ rekam medis melalui bedah dokumen yang dilakukan oleh peneliti. Lembar yang diteliti antara lain, meliputi: Lembar Ringkasan Masuk dan Keluar. Diperkuat dengan melihat Resume medis dan Lembar Operasi. Kemudian, didukung dengan melihat Lembar Anamnesa, Lembar Pemeriksaan 
Penunjang dan Catatan Terintegrasi. Proses Koding di RS Sumber Waras adalah dengan melihat pada lembar ringkasan masuk dan keluar kemudian melihat resume jika koder belum memahami tulisan/singkatan yang ditulis dokter. Jika ada operasi,koder juga melihat pada laporan operasi. Berdasarkan hasil wawancara,koding yang akurat didominasi oleh kasus obstetric,urologi dan kasus yang sering terjadi. Ketika mengkode koder sudah hafal dengan kode yang sering muncul. Sehingga pada kasus tersebut,banyak ditemukan kode tindakan yang sudah akurat.

\section{Ketidakakuratan Kode Tindakan pada Lembar Ringkasan Masuk dan Keluar Kasus Bedah Pasien Rawat Inap di Instalasi Bedah Sentral.}

Keakuratan dalam pemberian kode tindakan merupakan hal yang harus diperhatikan oleh petugas rekam medis, dalam pedoman rekam medis menjelaskan bahwa tenaga rekam medis sebagai seorang pemberi kode bertanggungjawab atas keakuratan kode dari suatu diagnosis yang ditetapkan oleh tenaga medis ${ }^{1}$. Koding tindakan juga harus tepat dan akurat untuk menghasilkan statistik yang berarti untuk membantu dalam perencanaan kebutuhan kesehatan bangsa ${ }^{2}$. Petugas rekam medis harus membuat koding sesuai klarifikasi yang tepat. Keakuratan kode penting dilakukan demi tercapainya pelaporan yang tepat berdasarkan kasus yang ada. Apabila hasil kodefikasi salah dan tidak optimal maka akan mempengaruhi pelaporan mortalitas, morbiditas serta statistik rumah sakit ${ }^{3}$.

Laporan tersebut masuk kedalam elemen akreditasi, rumah sakit harus mematuhi ketentuan dalam bagian ini sepanjang waktu dalam proses akreditasi. Walaupun demikian, ketentuan ini tidak diberi nilai seperti standar lain dalam survey ditempat. Rumah sakit akan dinilai antara memenuhi atau tidak memenuhi ketentuan ini. Jika rumah sakit tidak memenuhi ketentuan tertentu, maka rumah sakit akan diminta untuk segera memenuhinya atau terancam tidak mendapatkan akreditasi.

Salah satu faktor yang memengaruhi ketepatan kode tindakan adalah koder harus paham betul apa yang dicatat oleh petugas medis yang ditulis direkam medis pasien. Pada penelitian lain yang dilakukan oleh Pramesti dari 95 rekam medis cesarean section, sebanyak $64.21 \%$ rekam medis dengan kode yang tepat dan $35,79 \%$ rekam medis dengan kode yang tidak tepat. Penelitian yang dilakukan oleh Ardyanta terdapat $57.12 \%$ kode tindakan yang sesuai dan $42.88 \%$ kode tindakan yang tidak sesuai ${ }^{3}$. Dalam penelitian yang sama, Ardyanta memaparkan faktor kesesuaian kode disebabkan oleh petugas koding yang tidak mengkode tindakan dan belum adanya kebijakan tertulis dan prosedur tetap mengenai pelaksanaan kode tindakan, dan juga petugas belum ada job description yang jelas.

Berdasarkan uraian diatas, dari hasil penelitian tentang keakuratan kode tindakan bedah didapatkan jumlah kode tindakan akurat sebanyak $43,6 \%$ rekam medis dan tidak akurat sebanyak $56,4 \%$. Penelitian ini selaras dengan penelitianAtik, salah satu pengaruh ketepatan kode disebabkan oleh faktor yang sama, yaitu koder harus paham betul apa yang dicatat oleh petugas medis yang ditulis direkam medis pasien. Berdasarkan wawancara kode paling banyak tidak akurat, ditemukan pada kasus dengan kesalahan kategori dan tidak spesifik, hal ini karena koder tidak melihat langsung dari buku ICD-9- CM melainkan mencari ke Google.

Penyebab kesalahan kode tindakan bedah di RS Sumber Waras diketahui dengan melakukan observasi kemudian dilanjutkan dengan melakukan wawancara terstruktur, yang pertanyaannya hanya sekitar temuan saat observasi. Pertanyaan pada wawancara terstruktur ini ada 10 butir, diantaranya 5 butir mengenai Sumber Daya Manusiam (SDM) koder, dan 5 butir mengenai pelaksanaan koding dengan 5 responden yang merupakan petugas koder. Berdasarkan wawancara mengenai penyebab ketidak akuratan melihat dari SDM koder RS Sumber Waras, faktor yang mempengaruhi sebagai berikut:

a. Jumlah tenaga koder di RS Sumber Waras masih kurang;

b. Koder di RS Sumber Waras mayoritas sudah lulusan ilmu rekam medis,namun masih ada satu orang yang sedang proses menempuh ilmu rekam medis;

c. Koder belum sepenuhnya memahami tulisan dokter; 
d. Koder belum sepenuhnya hafal singkatan yang dibuat dokter;

e. 5 responden, hanya 2 responden yang sudah melakukan pelatihan koding.

Berdasarkan wawancara mengenai penyebab ketidak akuratan pada saat pelaksanaan koding dilapangan, dapat diuraikan sebagai berikut:

a. Di RS Sumber Waras belum ada SOP untuk koding tindakan;

b. Pengkodingan tindakan belum sepenuhnya dilakukan oleh koder,terkadang kode tindakan diisi langsung oleh perawat/dokter;

c. Pengkodingan tindakan di RS Sumber Waras belum sepenuhnya dilakukan langsung pada saat dokumen kembali keruang rekam medis;

d. Rekam medis RS Sumber Waras sudah memiliki buku ICD-9CM sebagai dasar dalam mengkode tindakan namun jumlahnya masih kurang;

e. Petugas koder RS Sumber waras belum fokus melakukan satu pekerjaan yaitu mengkoding, karena mereka juga dituntut untuk melakukan pekerjaan yang lain seperti assembling, analisis kuantitatif dan pendaftaran pasien.

\section{SIMPULAN DAN SARAN}

Berdasarkan hasil dan pembahasan mengenai keakuratan kode tindakan bedah pada lembar ringkasan masuk dan keluar di RS Sumber Waras Semester II Tahun 2017, dapat ditarik kesimpulan bahwa:

1. Keakuratan kodefikasi Tindakan Bedah pada 94 sampel rekam medis diperoleh dari hasil perhitungan bahwa data yang akurat sebanyak $43,6 \%$ rekam medis dan yang tidak akurat sebanyak $56,4 \%$ rekam medis dengan tindakan terbanyak pada tindakan Operasi Sesar..

2. Faktor yang menyebabkan ketidak akuratan kode, antara lain:

a. SDM Koder

Kurangnya jumlah koder di RS Sumber Waras juga perlunya koder dalam mengikuti pelatihan koding. Selainitu,koder belum sepenuhnya memahami tulisan dan singkatan yang ditulis oleh dokter.

b. Pelaksanaan Koding
Belum adanya kebijakan tertulis dan prosedur tetap mengenai pelaksanaan kode tindakan dan pelaksanaan tugas yang tidak sesuai dengan job description sehingga petugas tidak bisa langsung mengkoding saat berkas kembali dari ruang perawatan.Terbatasnya ketersediaan buku ICD-9CM juga mempengaruhi terhambatnya pelaksanaan koding.

Dari hasil penelitian dapat diberikan saran sebagai berikut :

1. Petugas koding harus melakukan konfirmasi kepada dokter / perawat jika ada tulisan atau singkatan yang tidak dapat di pahami;

2. Koder secara rutin mengikuti update pelatihan koding minimal satu kali dalam setahun;

3. Membuat SOP oleh pihak manajemen mengenai job description pada setiap petugas sesuai dengan kompetensi yang dimilikinya.

\section{DAFTAR PUSTAKA}

1. Keakuratan Kode Tindakan Kasus Bedah Pasien Rawat Inap Berdasarkan ICD-9-CM Di RS Panti Rapih Yogyakarta. etd.repository.ugm.ac.id,17;81-82.

2. Notoatmodjo, S. Metodologi penelitian kesehatan. Jakarta: Rineka Cipta;2011.

3. Depkes. RI,. Pedoman Pengelolaan Rekam Medis Rumah Sakit Indonesia. Jakarta;2006.

4. Dieleman, M., Cuong, P.V., Anh, L.V., dan Martineau, T., IdentifyingFactorsforJobMotivationofRur alHealthWorkers in NorthViet Nam. Human Resources forHealth. Vol. 1. No. 10;2003.

5. Hatta, Gemala R. Pedoman Manajemen Informasi Kesehatan di Sarana Pelayanan Kesehatan. Jakarta: Universitas Indonesia;2008.

6. Hatta, Gemala R. Pedoman Manajemen Informasi Kesehatan di Sarana Pelayanan Kesehatan revisi 2. Jakarta: Penerbit Universitas Indonesia (UIPress); 2013. 
Media Informasi

Volume 16 Nomor 1 Tahun 2020

Halaman : 23

7. Keputusan Menteri Kesehatan Republik Indonesia

Nomor:

377/MENKES/SK/III/2007 Tentang

Standar Profesi Perekam Medis.

8. Konsil Kedokteran Indonesia. Standar Kompetensi Dokter Indonesia. Jakarta;2012.

9. Maiga MN., Viva, Ansyon., Anis, Hariyanto., Tuti. Peran Pengetahuan dan Sikap Dokter dalam Ketepatan Koding Diagnosis berdasar ICD 10, Program Magister Manajemen Rumah sakit Fakultas Kedokteran Universitas Brawijaya, Malang;2014. 